\title{
Ectopic Thyroid Gland Thymoma
}

National Cancer Institute

\section{Source}

National Cancer Institute. Ectopic Thyroid Gland Thymoma. NCI Thesaurus. Code C156268.

A rare thymoma arising within or is attached to the thyroid gland. 